\title{
THE EVALUATION OF NITROGEN FIXATION ACTIVITY OF SOIL CYANOBACTERIA VIA REDUCTION ASSAY AND REAL TIME- PCR
}

Zahra Hojjati Bonab, †Parisa Mohammadi, Ezzat Asgarani, Nassim Ghorbanmehr

\begin{abstract}
Cyanobacteria, especially the nitrogen fixation, are considered as one of the most important bacteria in all aquatic and terrestrial environments and have vital roles in the arid and semi-arid ecosystems. Therefore, in the present study, cyanobacteria obtained from the harsh terrestrial ecosystem were selected and the nitrogen fixation activities were assayed by acetylene reduction and Real-Time Polymerase Chain Reaction (RT-PCR). First, the soil cyanobacteria were isolated by using the BG11 medium. Then, all the isolates were transferred into the nitrogen-free medium of BG11 (BG0). In addition, the rate of nitrogen fixation was assayed by gas chromatography mass based on acetylene reduction assay. Next, the nifH gene was expressed in the nitrogen fixation isolates utilizing the RT-PCR. Based on the results, the highest level of ethylene production was observed in Nodularia sp. with $86.3 \%$ yielding. Further, the RT-PCR data indicated that all the selected isolates could express the nifH gene. Furthermore, the nifH gene expression of Nodularia sp. and Trichocleus sp. was considerable compared to the other genera. Additionally, the activity of nitrogenase and its increase in the gene expression of nitrogen fixation were extremely higher than those of the filamentous and heterocystous cyanobacteria compared to the other genera. Therefore, cyanobacteria play a crucial role in the nitrogen fixation of the soil.

Key words: Cyanobacteria, NifH Gene, Nitrogen Fixation, Real-time Polymerase Chain Reaction Introduction. Nitrogen-fixing microorganisms are globally significant since they are the only natural biological source of nitrogen fixing in the biosphere $\left[{ }^{1,2}\right]$. In addition, cyanobacteria, as one of the most significant nitrogen fixating bacteria in all aqueous and terrestrial environments, have an essential role in arid and semi-arid ecosystems $\left[{ }^{3}\right]$. According to several studies, three main processes exist for nitrogen fixation including Haber-Bosch process (i.e., anthropogenic), lightning strikes (i.e., abiotic), and the biological response to $\mathrm{N}_{2}$ and $\mathrm{H}_{2}$ for producing the ammonia $\left[{ }^{4,5,6}\right]$. In the biological process, the complex of nitrogenase enzyme, which is very sensitive to free oxygen, catalyzes the nitrogen reduction to ammonium. This enzyme contains the dinitrogenase and dinitrogenase reductase proteins, which are of MoFe and $\mathrm{Fe}$ proteins,
\end{abstract}


respectively $\left[{ }^{7}\right]$. Further, dinitrogenase reductase is considered a homodimer of about $60-70 \mathrm{kDa}$ protein, which is encoded by the nifH gene $\left[{ }^{8}\right]$.

Therefore, different PCR primers were developed for the nifH gene in order to understand the procedure of nitrogen fixation using the environmental samples. Using the nifH as a genetic marker, the researchers could recognize and describe the diversity and ecological aspects of the nitrogen-fixation bacteria and archaea $\left[{ }^{9}\right]$. Furthermore, the nitrogen fixation rate was measured by the acetylene reduction assay (ARA) and Real-time quantitative PCR (RT-qPCR) methods which are commonly used in both axenic and non-axenic cyanobacteria [ $\left.{ }^{10,11,12}\right]$. The first assay demonstrated the reduction of acetylene gas to ethylene gas $\left[{ }^{13}\right]$. As described by Bergersefn, the nitrogenase enzyme converts acetylene to ethylene using the same amount of energy, which is required to fix the $\mathrm{N}_{2}\left[{ }^{14}\right]$. Based on the above-mentioned discussions, the present study sought to assay the rates of biological nitrogen fixation and nifH expression from cyanobacteria, which were isolated from the terrestrial ecosystem. Although many studies have focused on the nitrogen-fixing cyanobacteria isolated from the aquatic environment, reports on arid and semi-arid terrestrial are rare. Accordingly, the current study aimed to determine the nitrogen fixation potential of cyanobacteria from the harsh environment.

Materials and methods. Site Sampling. In this study, Cyanobacteria of arid and semi-arid Khabar International Park soil samples were isolated and identified through the microbiological and molecular method. Based on the level of nifH gene expression, the highest nitrogen fixation isolates were selected and compared with each other. Thereafter, the isolates were grown in continuously supplied $\mathrm{BG}_{0}$ medium and aerated by an aquarium pump [ $\left.{ }^{14,15,16}\right]$.

Determination of $\mathrm{N} 2$ fixation by the acetylene reduction assay. The isolated cyanobacteria were inoculated into $100 \mathrm{ml}$ tubes containing $50 \mathrm{ml}$ of $\mathrm{BG}_{0}$ broth medium and incubated in 34$38^{\circ} \mathrm{C}$. After 48 hours, $20 \%$ of the headspace was replaced with acetylene gas by using a $2.5 \mathrm{ml}$ syringe and incubated for 24 hours with the same temperature. Then, $2 \mu \mathrm{L}$ of air was injected into the each tube and GC/MS data were acquired by gas chromatograph (Agilent 7890B).

RNA extraction. RNA was extracted from 0.15 grams of cyanobacteria isolates. For this reason, Cyanobacterial cells were harvested via centrifugation at 500×g for $10 \mathrm{~min}$ (JA 20 rotor, Beckman) in three replicates. Pellets were immediately vortexed to resuspend the cells in $1 \mathrm{~mL}$ ice cold RNX ${ }^{\mathrm{TM}}$-PLUS solution and then dipped in liquid nitrogen. To break down the cyanobacterial 
cell wall, 5 cycles of snap freezing in liquid nitrogen, thawing in $70^{\circ} \mathrm{C}$ was carried out. Total RNA was extracted using phenol/chloroform extraction method $\left[{ }^{17}\right]$.

Quantity and quality of extracted RNA. Quantity and quality of extracted RNA were assessed using NanoDrop 2000 spectrophotometer (Thermo Scientific) and agarose gel electrophoresis, respectively. The RNA was quantified using the spectrophotometer at 260 and $280 \mathrm{~nm}$ wavelength. The quality of RNA was checked in a $2 \% \mathrm{w} / \mathrm{v}$ agarose gel. The electrophoresis was performed at $85 \mathrm{~V}$ in $0.5 \mathrm{x}$ Tris-borate EDTA (TBE) buffer for $45 \mathrm{~min}$. The RNA migration was visualized after GelRed $^{\mathrm{TM}}$.

DNase treatment and cDNA synthesis. All RNA samples for cDNA synthesis were adjusted to the same concentration. In order to remove potential contamination of genomic DNA and achieve pure cDNA, all samples were treated with DNaseI enzyme (Fermentase). According to the manufacturer protocol, cDNA was synthesized using the Prime Script ${ }^{\mathrm{TM}}$ RT Reagent (Takara kit Perfect Real Time). The total volume of the reaction was $10 \mu \mathrm{L}$, containing $500 \mathrm{ng}$ of RNA, $2 \mu \mathrm{L}$ of $5 \mathrm{X}$ buffer, $0.5 \mu \mathrm{L}$ RT enzyme, $0.5 \mu \mathrm{L}$ oligo dT primer and $0.5 \mu \mathrm{L}$ random hexamer and reached to the final volume with DEPC water.

Real Time PCR. Real time PCR was performed using Sybr® Premix Ex Taq ${ }^{\mathrm{TM}}$ II Takara kit. The Applied Biosystems ${ }^{\mathrm{TM}}$ StepOne ${ }^{\mathrm{TM}}$ Real time- PCR system was used to record changes in the fluorescence dye. Reactions were performed in a total volume of $12.5 \mu \mathrm{l}$, containing $4 \mu \mathrm{cDNA}$ template (diluted 1:20), $6.25 \mu \mathrm{l} 2 \mathrm{X}$ SYBR green master mix and $0.1 \mu \mathrm{M}$ of each forward and reverse primers of nifH or $16 S$ rRNA according to the table. $\left.1{ }^{18,19}\right]$. The relative expression of nifH was assessed in comparison to $16 \mathrm{~S} r R N A$, as an internal control reference. The experiments were carried out twice and each time in triplicate. All controls were excluded of primers. The real time- PCR was conducted according to this program: initial activation phase at $95^{\circ} \mathrm{C}$ in 1 minute, denaturation phase at $95^{\circ} \mathrm{C}$ in 5 seconds, annealing phase at $60^{\circ} \mathrm{C}$ for 34 seconds, and was repeated for 40 times. The gene expression of $n i f H$ were determined in different groups using $2^{-\Delta c t}$ method. 
Table 1. The primers of Cyanobacteria used in RT-qPCR

\begin{tabular}{|c|c|l|c|}
\hline Name & Primer & Primer Sequence (5' to $3^{\prime}$ ) & PCR Product Length \\
\hline nifH & Forward & CGTAATGCTCGAAGGGTTTGAA & \multirow{2}{*}{$79 \mathrm{bp}$} \\
\hline nifH & Reverse & CACGACCAGCACAACCAACT & \\
\hline $16 \mathrm{~S} r R N A$ & Forward & CAGTAGCTGGTCTGAGAGGATG & \multirow{2}{*}{$150 \mathrm{bp}$} \\
\hline $16 \mathrm{~S} r R N A$ & Reverse & GTTTACAACCCAAGAGCCTTCC & \\
\hline
\end{tabular}

Statistical and analysis. Statistical analysis was performed using SPSS software (version 22).

The data were presented as mean \pm standard deviation (SD) and the ANOVA test was employed to determine the significance of the observed differences between groups. P value less than 0.05 was considered statistically significant.

Result. A total of nine cyanobacterial isolates including Chroococcidiopsis $\mathrm{sp}$. ( $\mathrm{n}=5)$, as well as Leptolyngbya sp., Synechococcus sp., Nodularia sp., and Trichocleus sp. (one out of each genus) was tested. Additionally, all the isolates were identified by both morphological and molecular methods.

In addition, the nitrogenase activity of the bacteria was detected in a $\mathrm{BG}_{0}$ medium using a nifH marker gene. Then, the species were grown in nitrogen-free medium, followed by nitrogen fixation assay through measuring the ethylene production. Among the isolated bacteria, Nodularia sp. could convert a large percentage of acetylene to ethylene and was introduced as the best nitrogenfixation bacterium. The production of ethylene was detected in peak at $0.968 \mathrm{~min}$. Further, the highest level of ethylene production was observed in Nodularia sp., yielding 86.3\%. Furthermore, Trichocleus sp. converted a lower percentage of the acetylene to ethylene. For this second strain, ethylene was detected in peak after $1.096 \mathrm{~min}$. The yield of ethylene for Trichocleus sp. was $73.6 \%$.

\section{RNA extraction result}

The quantity of RNA measured by the nanodrop2000 indicated a high yield of RNA. Additionally, the purity of RNA was estimated by calculating the ratio between the absorbance at 260 and 280 $\mathrm{nm}$. The A260/A280 ratio was around 2 for the majority of RNA samples (three replicates), which represents a sufficient quality of RNA without any protein contamination.

\section{RT-PCR result}


The nifH, as a marker gene, was used to study the diversity and ecology of nitrogen-fixing bacteria. The results demonstrated that the nifH gene expression in the Nodularia sp. was more than that of the other strains. In addition, the highest level of nifH gene expression was observed in Nodularia sp., followed by Trichocleus sp., Synechococcus sp., and Leptolyngbya sp while the lowest level of nifH gene expression belonged to Chroococcidiopsis sp. (Ch28A). As shown in Fig. 1, there is a significant difference between the samples in terms of the nifH gene expression $(\mathrm{P}<0.05)$.

Further, the melting curve of the RT-PCR reactions has a sharp peak of $\mathrm{T}_{\mathrm{m}}$ of the products, which represents that all the RT-PCR reactions amplify the DNA target.

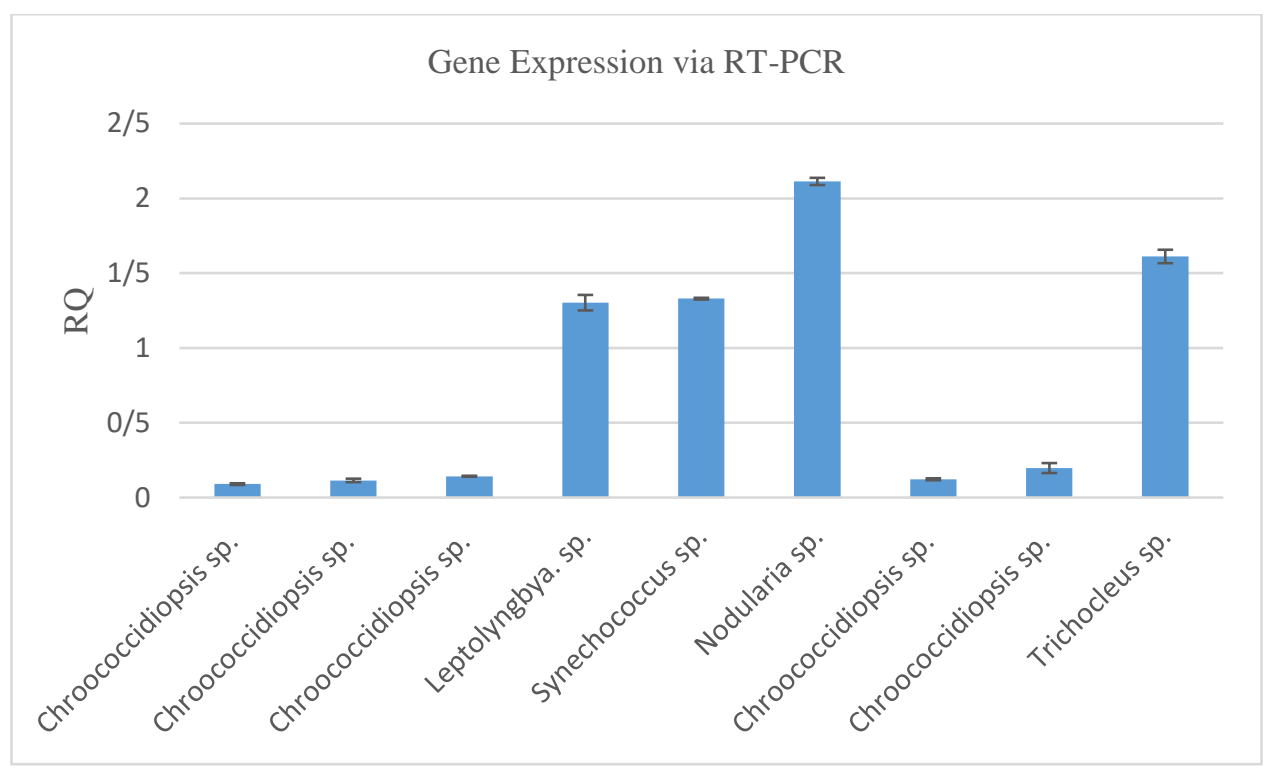

Fig. 1. The comparison of nifH gene expression in cyanobacterial isolates Note. The expression of the nifH gene is the highest in Nodularia sp. while it is the least in Chroococcidiopsis sp. (Ch28A). Furthermore, the results demonstrate $\mathrm{SD} \pm \mathrm{P}$-value $<0.05$ of the three replicates.

Discussion. Cyanobacteria are regarded as one of the natural biological sources of nitrogen fixing in nearly all the habitats. Based on the quantitative results regarding nifH gene expression and $\mathrm{N}_{2}$ fixation obtained from the RT-PCR analysis, significant differences were found between the samples, indicating that the expression of the nifH gene was higher in Nodularia sp. and Trichocleus sp. compared to the other species. Based on the reports, the rate of expression of nif operon in the filamentous and heterocyst cyanobacteria was higher than that of the other 
microorganisms $\left[{ }^{19}\right]$. Additionally, in this study, the heterocystous cyanobacteria exhibited more nitrogenase activity compared to the other species isolated from the arid and semi-arid areas.

Bauer reported the dominance of non-heterocystous cyanobacteria in most of the studied sites and the maximum levels of nitrogenase activity during the dark period and found that the oxygen level was the minimum in the cells $\left[{ }^{20}\right]$.

In addition, it was found that the expression of the nifH gene and nitrogen fixation in the filamentous and heterocyst cyanobacteria was greater in hot and intact areas compared to the other cyanobacteria areas of the desert. This can be attributed to the presence of various factors such as organic matter and carbon, nitrogen, the amount of light irradiation absorbed on the surface, and the temperature of the region $\left[{ }^{3}\right]$.

The highest level of ethylene production was observed in Nodularia sp. Several studies reported that nifH is used as the most important functional gene for studying the structural and functional diversity in different environments [ $\left.{ }^{16,19}\right]$. Further, the high levels of ammonium produced by the high activity of the nitrogenase increase further NH4 + stabilization.

\section{Conclusion}

In general, the analysis of the Real-time Polymerase Chain Reaction revealed significant differences between nifH gene expression and nitrogen fixation among the strains, which was confirmed by measuring the total nitrogen fixation in the sample using the acetylene reduction assay method.

\section{Acknowledgements}

The authors would like to appreciate Dr. Gholipour-Shahraki for her helpful technical assistance. Furthermore, special thanks go to the Vice Chancellor of Alzahra University for financial support, as well as all the staff of Shayesteh Sepehr Laboratories of Industrial Microbiology for their cooperation.

\section{REFERENCES}

[1] JOHN-CHRISTIAN G.H., A. DANIEL, BUCKLEY (2012) Comprehensive evaluation of PCR primers to amplify the nifH gene of nitrogenase. Journal. Pone. 0042149. PLOS ONE. Www.plosone.org. 
[2] GRAHAM L.E., L. WILCOX (2000) Algae. Upper Saddle River. NJ. Prentice Hall.

[3] MEEKS J.C., E.L. CAMPBELL, M.L. SUMMERS, F.C.WONG (2002) Cellular differentiation in the cyanobacterium Nostoc punctiforme. Archives in Microbiology.178, 395403.

$\left.{ }^{4}\right]$ GALLOWAY J.N., F.J. DENTENER, D.G. CAPONE, E.W. BOYER, R.W. HOWARTH et al. (2004) Nitrogen cycles: past, present and future. Biogeochemistry J. 70, 153-226.

[5] GALLOWAY J.N., A.R. TOWNSEND, J.W. ERISMAN, M. BEKUNDA, Z. CAI et al. (2008)

Transformation of the nitrogen cycle: recent trends, questions and potential solutions. Science J. 320, 889-892.

$\left[{ }^{6}\right]$ ERISMAN J.W., M.A. SUTTON, J. GALLOWAY, Z. KLIMONT, W. WINIWATER (2008)

How a century of ammonia synthesis changed the world. Nature Geoscience J. 1, 636-639.

[7] MADIGAN M.T., J.M. MARTINKO, J. PARKER (1996) Brock Biology of Microorganisms (8th Ed). Upper Saddle River, N J. Prentice Hall.

$\left[{ }^{8}\right]$ TAMAGNINI P. (2002) Hydrogenases and hydrogen metabolism of cyanobacteria. Microbiology and Molecular Biology J. 66(1), 1-20.

[9] MAN- AHARONOVICH D.N., E. KRESS, I. BAR ZEEV, O. B. BERMAN-FRANK (2007) Molecular ecology of nifH genes and transcripts in the eastern Mediterranean Sea. Environ Microbiol. J. 9, 2354- 2363.

$\left[{ }^{10}\right]$ LEVITAN O., G. ROSENBERG, I. SETLIK, E. SETLIKOVA, J. GRIGEL et al. ( 2007) Elevated $\mathrm{CO} 2$ enhances nitrogen fixation and growth in the marine cyanobacterium Trichodesmium. Global Change Biology J. 13, 531-538.

[11] CZERNY J.J., R. BARCELOSE, U. RIEBESELL (2009) Influence of elevated CO2 concentrations on cell division and nitrogen fixation rates in the bloom forming cyanobacterium Nodularia spumigena. Biogeosciences J. 6, 1865- 1875.

$\left[{ }^{12}\right]$ CHINNASAMY S.B., A. RAMAKRISHNAN, S.K. BHATNAGAR, K.C. GOYAL (2009) Carbon and nitrogen fixation by Anabaena ferilissima under elevated $\mathrm{CO} 2$ and temperature. Freshwater Ecology J. 24, 587-596.

$\left[{ }^{13}\right]$ DANIEL H.B.G, P. SIMON, P. SERGE, W. A. DOLORS (2006) Identification of two genera of $\mathrm{N}_{2}$-fixing cyanobacteria growing on three feather moss species in boreal forests of Quebec, Canada. Canadian Journal of Botany. 84(6), 1025-1029. 
[14] BERGERSEFN J. (1970) the quantitative relationship between nitrogen fixation and the acetylene reduction assay. Australian Journal of Biological Sciences. 23, 1015-1025.

[15] STANIER R.Y., R. KUNISAWA, M. MANDEL, G. COHEN-BAZIRE (1971) Purification and properties of unicellular blue-green algae (order Chroococcales). Bacteriol Rev J. 35,171-205. [16] SIVONEN K., E. KONONEN, S.I. NIEMELA (1989) Toxicity and isolation of the cyanobacterium Nodularia spumigena from the southern Baltic Sea in Hydrobiology J. 185, 3-8. [ $\left.{ }^{17}\right]$ BYUNG-HYUK K.O., L. HEE-MOCK, C. YOUNG-KI, A. GANG-GUK ,Y. CHI-YONG (2006) Simple method for RNA preparation from cyanobacteria. Journal of phycology. 11371141.

$\left.{ }^{[18}\right]$ CATARINA C.V., P. ELISABETE, V. PAULO, VITOR (2015) Applicability of the real-time PCR assay in the amplification of cyanobacterial DNA from preserved samples. Limnetica J. 34 (1), 173-186.

[19] KENDRA A.T., P.R. ANDREW, P.Z. JONATHAN, P. NICOLE, S. PAUL et al. (2011) Nitrogen fixation and nitrogenase $(\mathrm{nifH})$ expression in tropical waters of the eastern North Atlantic. International Society for Microbial Ecology J. 5, 1201-1212.

$\left[{ }^{20}\right]$ KAROLINA B. (2007) Diazotrophy and diversity of benthic cyanobacteria in tropical coastal zones. Department of Botany, Stockholm University. pp: 1-48.

*Department of Microbiology

Faculty of Biological Sciences

Alzahra University

Tehran, I.R.Iran

E- mail: Hojjati_zahra90@yahoo.com †p.mohammadi@alzahra.ac.ir

\section{Department of Biotechnology \\ Faculty of Biological Sciences \\ Alzahra University \\ Tehran,I.R.Iran}

E-mail: asgarani@gmail.com nassim.ghorbanmehr@gmail.com 